\title{
真空精留と分子蒸留装置
}

中 川洋

日本酸素株式会社東京製作所（東京都大田区下丸子 2 の 12 の 15）

\section{Vacuum Fractionating Apparatus and Molecular Distillation Equipments}

Hiroshi Nakagawa

Nippon Sanso K.K. (Japan Oxygen Co., Ltd.), Tokyo Factory (2-12-15 Shimomaruko, Ōta-ku, Tokyo)

\section{1 まえがき}

石油や油脂工業において, 製品精製には蒸留操作が久 くぶからざる重要な手段として古くから広く使われてい る。したがってこの方面の工業に対する蒸留操作の応用 については，もはやとくに問題とするような点もないよ うに思われる。

しかし, 石油工業, 油脂工業に限らず, 一般の化学工 業においても製品品質の純度への要求, 製品歩留り向上 への要請は非常にきびしいものがある一方, 精製工程の 合理化, すなわち装置の設備費, 運転費, 保守費をでき る限り軽減させる必要があり, 蒸留装置の能力, 性能に 対する向上の要望浪躍的に高まったといえよう。この ため従来の小型装置を単に大型装置に置き換えるという のではなく，新しい原理に基づいたより高い性能の装置 にしたり，従来は実用的でないと考えられていた操作条 件で運転したり，ほとんど人手を要しない自動制御連続 装置を考えたり，いろいろと新しい試みが数多く行なわ れている。

一般化学工業に応用される蒸留操作の取り上げ方に対 して, 石油工業と油脂工業方面では, 比較的保守的な色 彩が濃く, とくに油脂工業では戦前からの蒸留器をその まま用いている例も少なくないし，また新設されたもの でも, 原理や構造が昔のままということもまれではな い。一方石油工業に使われる蒸留器といえば, コンビナ 一トにそびえ立つ大きな精留塔を思い出すように，もは や技術的にはなんらの改良の余地もないように思われ る。

このようにきわめて伝統を重んずる分野にも，今や新 しい試みを実施して, 能率, 品質の向上を計る必要が日 一日と強くなっているように思われる。

本稿では, 最近のこの方面の進歩を含めて，主として 真空精留と分子蒸留の装置について解説する。

\section{2 真空蒸留の必要性}

本稿では, 真空を併用した蒸留装置について解説する のであるが，各論にはいる前に，なぜ真空を併用するか という点, および, 真空を併用することによって生ずる いろいろのトラブルについて触れておきたい。とくに真 空を利用することによって生ずる利点を最大限に発揮す ることが, 新しい装置を考えたり, 従来の装置の能力, 性能を向上させる最大のポイントであるから，その理由 をよく考察しておくことは決して無意味ではないと思 亏。

\section{$2 \cdot 1$ 沸点の低下}

当然のことながら，物質の沸点は真空下に置かれれ ば，常圧下よりも低下する。一般に真空蒸留を採用する 目的の第一はこの点にあるわけで, 操作温度をできる限 り下げて, 物質の分解, 重合を極力防止しようとするの である。しかし，すべての場合に，操作圧力が低ければ 低いほど良いかというとそうではなく，たとえば，コン デンサーにおける凝縮温度も下がり，通常の冷却水では 間に合わなくなったり，留分が凝結したり高真空にする ための排気装置が膨大なものになったりするので，適当 な圧力で妥協することになる。

表-1 は著者の経験から, きわめて大体の操作圧を, 扱ら物質の分子量から分類してみたものである。分子量 と蒸気圧とは決して一定の関係にあるわけではないが，

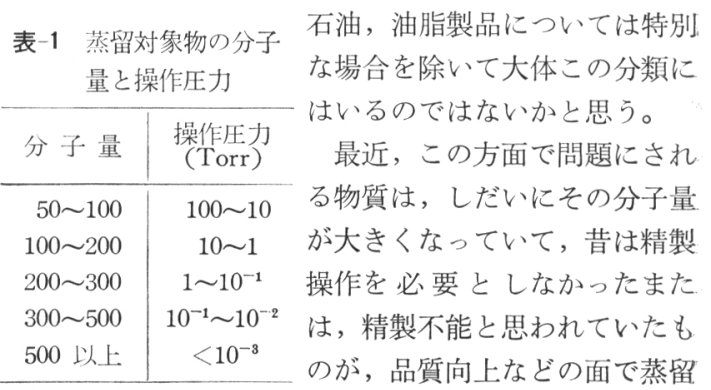


精製を要求されるようになった例が多い。このような場 合当然真空下の蒸留が必要となる。

\section{$2 \cdot 2$ 物質の分解, 重合}

真空下で沸点を下げて, 蒸留温度を低くすることによ って，物質の分解，重合を执さえることはできるが，その ほかにも考慮すべき問題がある。すなわち, 物質の変質 は温度のみでなく, 高温に保たれている時間にも関倸す る。分解, 重合速度が操作温度と滞留加熱時間のどのよ らな関数であるかは, 種々論義のあるところで, また物 質によっても相当違らであろらが，ここでは Hickman ${ }^{1)}$ の説に従って操作温度が $10^{\circ} \mathrm{C}$ 上がるごとに分解速度が 2 倍になり, また分解反応は滞留時間に比例するとす る。ジベンジルフタレイトを例にとってこの Hickman 説による分解の危險性は 表-2 のようになる。この表は 厳密汇成立するわけではなく, 大体の傾向を示すもので ある。

ここで, 物質の分解, 重合を防ぐためには, 操作圧力 すなわち操作温度を下げるだけでなく, 滞留時間を減少 するよう考慮すべきであり，ときにはその方が効果が大 きいこともあることに注意せねばならない。この点, 昔 ながらの回分式の蒸留ガマは少なくとも真空蒸留にはあ まり向いていないといらべきで, 最近の真空蒸留器は, すべて滞留時間を短くするよう考虑されている。とくに 表-2 からわかるように, 遠心式分子蒸留器は, ほかの いかなる方法に比べても分解, 重合の危険性が少ない。

表-2 各種の真空蒸留に出ける分解の危険性

\begin{tabular}{|c|c|c|c|c|c|}
\hline & $\begin{array}{l}\text { 操作压力 } \\
\text { (Torr) }\end{array}$ & $\begin{array}{l}\text { 蒸留温度 } \\
\left({ }^{\circ} \mathrm{C}\right)^{*}\end{array}$ & 温度侎 & $\begin{array}{c}\text { 系 加熱時間 } \\
(\mathrm{sec})\end{array}$ & $\begin{array}{l}\text { 分解危険 } \\
\text { 䓍比*** }\end{array}$ \\
\hline 工業用回分蒸留ガマ & 760 & 360 & $2^{23}$ & $10 \times 3,600$ & $1.5 \times 10^{13}$ \\
\hline 常压フラスコ蒸留 & 760 & 360 & $2^{23}$ & $1 \times 3,600$ & $1.5 \times 10^{12}$ \\
\hline 低真空回分蒸留ガマ & 100 & 320 & $2^{19}$ & $10 \times 3,600$ & $9.5 \times 10^{11}$ \\
\hline 高真空回分蒸留ガマ & 10 & 270 & $2^{14}$ & $10 \times 3,600$ & $3.0 \times 10^{10}$ \\
\hline $\begin{array}{l}\text { クライゼンフラスコ } \\
\text { 真空蒸留 }\end{array}$ & 3 & 250 & $2^{12}$ & $1 \times 3,600$ & $7.4 \times 10^{8}$ \\
\hline フラッンュ蒸留器 & 1 & 220 & $2^{9}$ & 60 & $1.5 \times 10^{6}$ \\
\hline 実験用ポットスチル & $10^{-2}$ & 170 & $2^{4}$ & $1 \times 3,600$ & $2.9 \times 10^{6}$ \\
\hline 流下膜式分子蒸留器 & $10^{-3}$ & 130 & 1 & 20 & $1 \times 10^{3}$ \\
\hline $\begin{array}{c}\text { 遠心式 分子蒸留器 } \\
\text { (工業用 }\end{array}$ & $10^{-3}$ & 130 & 1 & 1 & $5 \times 10$ \\
\hline (実験用) & $10^{-3}$ & 130 & 1 & 0.02 & 1 \\
\hline
\end{tabular}

*ジペンジルフタレイトの場命仮定した。

** 温度が $10^{\circ} \mathrm{C}$ 上昇すると, 分解, 重合か 2 倍の速をて起こるとした。

*** (温度係数 $) \times($ 加熱時間)。実験用遠心式分子蒸留器を 1 とした。

一方, 真空にすることによって, 蒸留している物質に 触れる酸素の量が少なくなるために, 酸化作用がおさえ られるといら利点も考えられる。しかしこの点をよく考 えてみると, 普通の石油や油脂関倸の真空蒸留の操作圧 力, すなわち 10 100 Torr 程度では, 酸素の存在量は 大気と比較して $1 / 10 \sim 1 / 100$ 程度には減っているが， 物質が酸化するためにはいまだ充分多量に存在するとみ てよい。また, 石油や油脂の分解, 重合は酸素の存在量 だけによって決まる訳でもなく, 自動酸化のように酸素
の存在量に無関係に進む場合もある。

このように普通の真空蒸留では，真空にするこ上によ って, 酸素の作用がなくなると考えるのはちょっと無理 であって, 分子蒸留のように $10^{-3} \sim 10^{-5}$ Torr になった 場合にはある程度正しい考え方であるといえよう。

ただ, 装置からの漏えいについて, 気相中への漏えい はほとんど問題にならないが, 液相中への漏えいは非常 に分解, 重合を促進することが多い点を注意せ福ばなら ない。たとえ装置に大容量の排気装置がついていて, 多 少の漏えいがあっても所定の圧力に引き切ることができ る場合でも, 液相に対する漏えいがあると, 濃、酸素 （といっても空気であるが）を高温の液に吹き込んでい ることになり，その影響は決して無視できない。さら に, 液相への漏えいがある場合, 普通の漏えいテストで はなかなか発見できないこともあって, 原料が酸化, 分 解, 重合を起こしているのを, その物質の特性であると 考えている場合も多いようである。

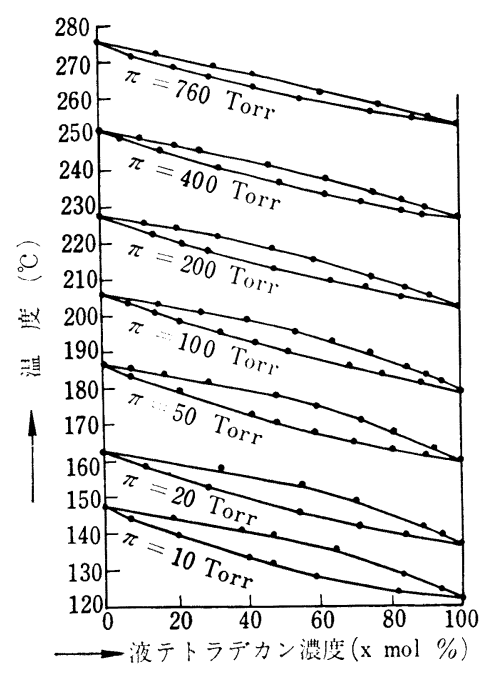

図-1 テトラデカンーへキサデセンの平衡曲線

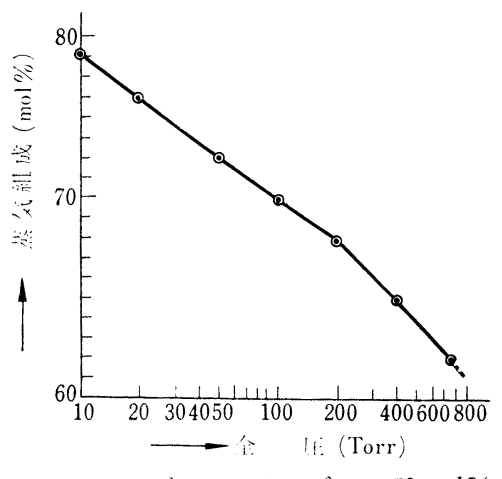

図-2 テトラデカンーへキサデセン $50 \mathrm{~mol} \%$ $50 \mathrm{~mol} \%$ 混命液と平衡にある蒸気の組 成 


\section{$2 \cdot 3$ 分離効率}

低圧においては，一般に物質の蒸気圧が，常圧のとき 上りも低下すると同時に, 二つ以上の物質の混合物の各 成分の示寸蒸気分圧の比が，常圧下の比よりも大きくな る。いいかえれば比揮発度は低圧になればなるほど大き な值を示す。図-1に示したのは，その一例であって， 混合液から発生する蒸気の組成が，低圧になればなるほ ビ，液の組成と違うことを示している。たとえばA成分 と B成分の $1: 1$ の混合溶液を苲留した場合, 常圧なら 壮，図-2 に示すように A 成分 $62 \%$ の蒸気が発生する が 100 Torr ならば 69\%，10 Torr ならば 77\%にも 達する。すなわち真空にすることによって，一般に分離 効率が大きい点は, とくに精留のように, 多数の蒸留段 を要するときはきわめて有効に利用される。

さらに，成分によっては共沸物を生成する場合は，第 三成分を加えて，いわゆる共沸蒸留，抽出蒸留などを行 なわなければならない場合，真空下で共沸点が消滅する 現象を利用できる場合もある。

分子蒸留の場合は, 常圧また減圧下の比揮発度とは 全然異なった分子比揮発度といら值を分離の指標として 用いなければならない。詳しいことは省略するが， A， $\mathrm{B}$ 二成分のある温度における純成分の蒸気圧をおのお の $P_{A}, P_{B}$ とすると, 常圧蒸留ではラウール法則に従 う系の比揮発度は $P_{A} / P_{B}$ に比例するが, 分子蒸留では $P_{A} \sqrt{M_{B}} / P_{B} \sqrt{M_{A}}\left(M_{A}, M_{B}\right.$ は分子量) に比例すると いう差異がある。

\section{4 真空を用いることによるトラブル}

第一に排気装置を必要とし，装置の気密を保た攻ばな らない。これは確かに常圧の装置に比較して余分な設備 ではあるが, 最近の真空技術の発達によって, 大容量, 高性能の排気装置が容易に得られるようになったし, 気 密の問題も, 常圧であっても漏えいのない装置を要求さ れるような時代になったことを考えれば，この点は根本 的なトラブルとはいえない。

それよりも，真空下では，液へッドによる静压が，全 体にかかっている圧力に比較して無視できないために， 沸騰現象を用いることができない，したがって伝熱係数 が小さいといら方がょり問題であろう。一般に真空蒸留 の効率が悪いと称せられるのは，この点核対する対策が 不充分の場合が強く印象づけられているゆえである。こ の問題も, 適当な対策, すなわち強制循環を行なうなど によって解決できる。

\section{3 真 空 精 留}

前述のように, 最近は石油, 油脂関倸で取り扱う物質 の分子量がしだいに大きくなり，乙かも製品の品位も高 純度のものが要求されるようになったので，とくに真空 精留の必要性はますます強くなってきた。
一般の精留において，段効率のなるべく良いタナ板， または理論段当たりの長さ (HETP) のなるべく短い充 テン塔が要求されるが, 真空精留においてはとくに圧力 降下の少ないという要請も加わる。一般に，段効率また は理論段長さは圧力降下と反比例の関係にあり,この両 者は相反する要求であることは良く知られている。した がって両者をどこで妥協させるかが大きな問題である。

\section{$3 \cdot 1$ タナ段塔}

常圧精留に用いられるホウ鐘板 (バブルキャップトレ 一), 穴明板 (シーブプレート)をそのまま真空精留に 用いている例が多いが，このままでは，大体段効率 70 〜 50\%, 一段当たりの圧力降下 3〜5 Torr といった值 を示す。しかし, 現在真空精留に要求される性能は段効 率 $50 \%$ 程度, 圧力降下は 1 Torr 以下であって, もは や普通の精留板では満足できないようになった。

このような精留板に対する研究は比較的遅れていて, いまだ決定的な構造というものは公表されてはいない が, 著者の経験ではターボグリッド精留板が比較的満足 すべき性能を示すように思う。

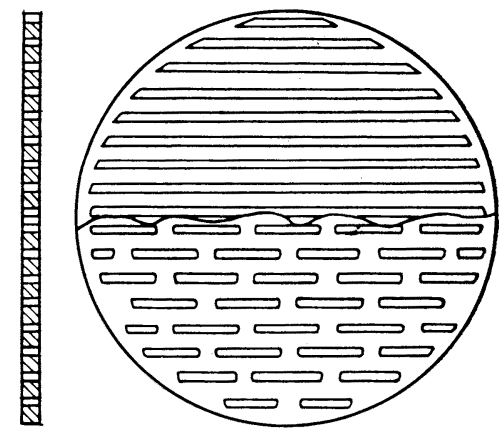

図-3 ターボグリッド板の構造 2 例

ターボグリッド板は主として石油の精留用として開発 された 図-3に示すごく簡単な構造の精留板であり, 普 通はダウンカマーを備えていない。液は, 板にあけられ た穴を通じて落下し，一方，蒸気も同じ穴を上昇する。

このように，気一液の接が普通の精留板と違う状態で 起きるので, 運転条件も普通の精留板とは違ってくる。

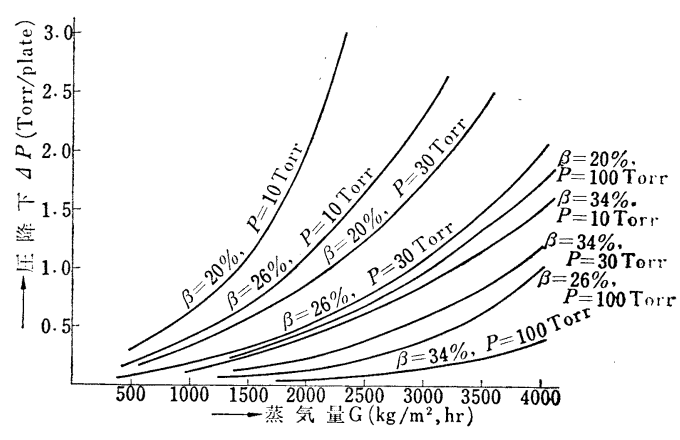

図-4 ターボグリッドの圧降下特性 
文献には,ターボグリッド板は，構造が簡単であり，価 格が安いという特長の代わりに, 段効率が劣り, 処理量 の許容範囲が狭いと記載されているが，これを真空精留 に用いた状態での性能は 図-4 に示したように比較的す ぐれたものであると考えられる。とくに各段当たりの圧 降下を 1 Torr 以下に抑えることは，ダウンカマーのあ る普通の精留板ではほとんど不可能であり，しかも 10 Torr 付近の高真空でも段効率 $50 \%$ を保つものとして は，ほかに類をみないものではないかと思われる。

\section{$3 \cdot 2$ 充 テン塔}

真空精留に関する現在まで発表されたデータは，ほと んど充テン塔に関するものである。これは，主として， 研究室規模の精留実験では, タ十段塔よりも充テン塔の 方が製作しやすいし，また性能もすぐれているからであ ろう。

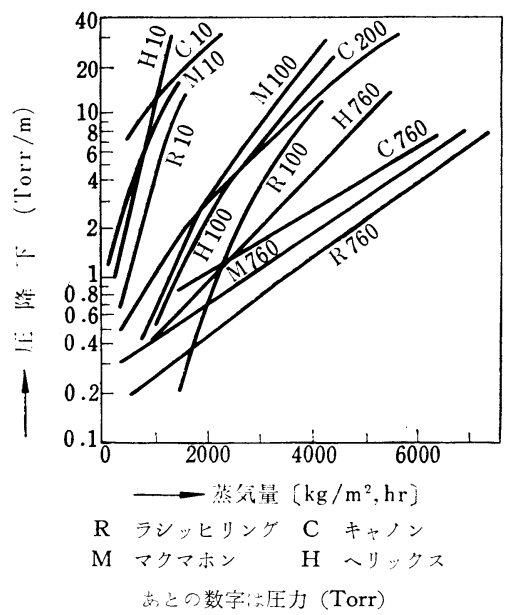

図-5 充テン物の圧降下

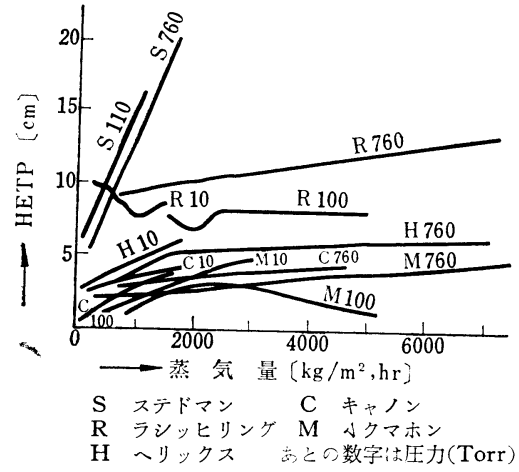

図-6 充テン筒の HETP

充テン塔の真空下における性能の研究は比較的多く発 表されている2)。とくに筒径 $100 \mathrm{~cm}$ までの小型の実験 用の塔については, 非常に詳しい報告が多数出ている。 こ礼らのうち, 二, 三の例を図-5，図-6 に示す。
真空精留に最も普通に用いられる充テン物は, マクマ ホンパッキング, ラシッヒリング, ヘリックスパッキン グなどで, 特に精密な蒸留にはステドマンパッキングな どが用いられる。

工業的な大型の塔では，充テン物の価格がかなり高い ので，特に製作に手間のかかるマクマホンパッキングな どでは充テン物だけで, 数千万円円の価格になることもあ る。

このため前述のように, 工業用精留塔としてはタ十段 塔が多く用いられるのであるが，圧降下をできるだけ少 なくするために比較的安価なラシッヒリング，ポールリ ングなども好んで用いられている。とくにポールリング は安価な割に精留効果もすぐれていて，工業的に使用す る目的には最も適した充テン物といえよう。

充テン物に関する研究は数多くあるが，10 Torr 以下 の高真空における性能はほとんど発表されていない。最 近のように，操作圧力の非常に低い，すなわち 2 3 Torr における真空精留が要求される場合，圧力降下は 比較的簡単に推定できるが，理論段当たりの筒長などは 推定が著しく困難である。これはなにも真空下に限った ことではなく，一般的に充テン塔における気一液の流れ 方，すなわち，チャンネリング，ブロッキングなどの現 象は, 非常に複雑であり, 安定した運転を行なうために は注意深く設計された塔を使用する必要があり，とくに 2 3 Torr 程度の真空精留塔の選択, 設計は非常に困難 な問題であることを付言しておく。

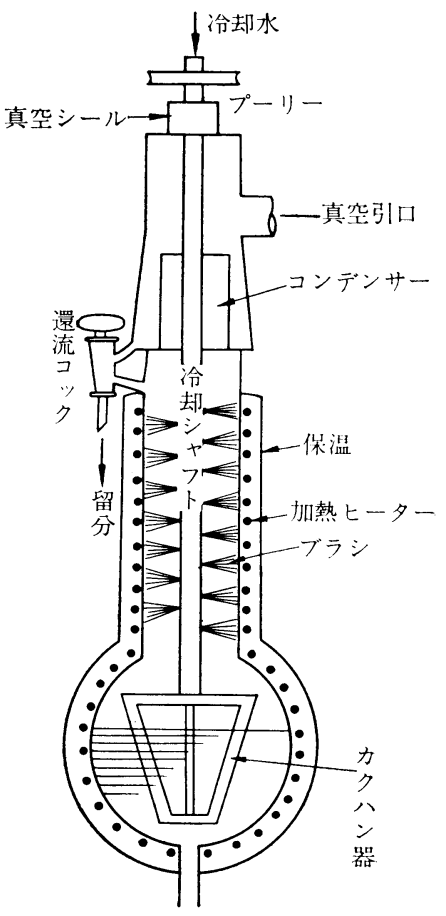

図-7 ブラシスチル 


\section{$3 \cdot 3$ 特殊な真空精留装置}

タナ板塔, 充テン塔において,一般には一理論段当た りの圧力降下は 3 5 Torr であり, 非常に上手に設計 された筒でも，1 Torr 内外であることを述べたが，最 近の要求はさらにきびしく, もっと圧力降下の少ないも のが出現することを期待している。段効率や理論段当た りの長さをぎせいにしないでこのような要求に答えるた めには, 気一液の接触を, 蒸気の上昇力と, 液の流下力 とだけにたよっていたのでは不可能であって，なんらか の機械的操作を導入して気一液接触を促進させる必要が 亦る。

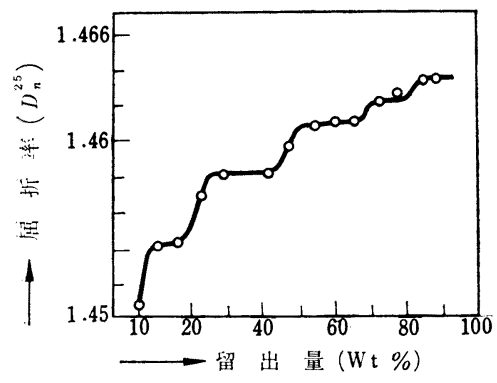

我リエチレンケリコールの精留圧力 $1 \times 10^{-3}$ Torr

図-8 ブラシスチルの性能

このような例として図-7 に示したブラッシュ精留 器 ${ }^{31}$ は, 蒸気が筒の中心で $400 \sim 800 \mathrm{rpm}$ で回転してい る泠却筒で凝縮し，液はそこから,ブラシの毛を伝って， 加熱面へ送られ，そこでふたたび蒸発するものである。 この方式では, 蒸気が液を貫くための圧力降下がないの で, 全体の圧力降下はきわめて少なく, また, 液はブラ シの作用によって配分されるので, 効率もきわめてよ い。図-8 はこの蒸留器によって, ポリエチレングリコ 一ルを精留した結果である。この結果から 1 HETP は 約 $50 \mathrm{~mm}$ であると測定された。

回転力を利用したものも，多数研究されている。図-9

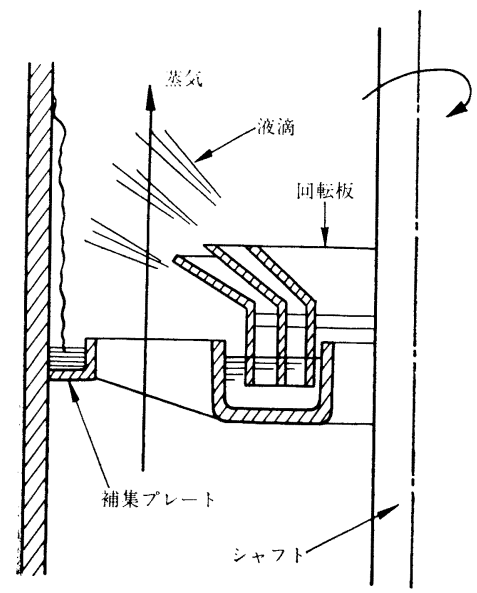

図-9 キルシバウム蒸留器

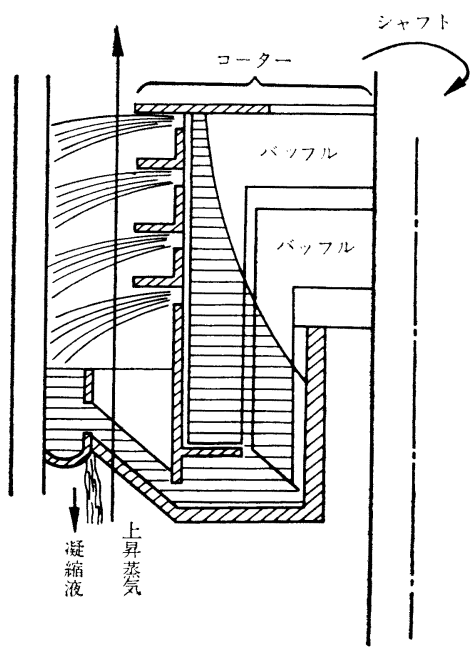

図-10ロータリートレイ

に示したのはその一例で, ロータリーカラム精留塔(4) は 回転する円筒のところどころに液を飛ばすみぞがついて いて,ここから凝縮液を加熱面に液滴としてもどすよう になっている。円筒の代わりに，冷却された板，または 金網が回転するものを，スピニングバンド精留塔) と称 している。

さらに, 多少大型の回転精留塔として, 図-10 に示し たような形式が発表されている。原理的には，上述のも のと大差なく, 液滴を回転力によって飛び散らせて, そ の間を蒸気が上昇するとき，気一液接触を行なわせるも のである。表-3 はこのような蒸留器の一例のロータリ ーコーン精留塔6) の性能を示したものである。

さらに, この蒸気をインペラーで圧縮し, 圧降下が逆 になるようなコンプレッション精留塔》などが考えられ ている。このように，機械的操作の導入は回転力が最も 簡単であるから，精留効果をあげるために回転力を導入 した精留塔がいるいると考えられているが，工業的規模

表-3 ロータリーコーン蒸留器の性能

\begin{tabular}{|c|c|c|c|c|}
\hline $\begin{array}{l}\text { 回転数 } \\
\text { (rpm) }\end{array}$ & $\begin{array}{c}\text { 液 } \\
(\mathrm{ml} / \mathrm{min}\end{array}$ & $\begin{array}{l}\text { 压降下 } \\
\text { (Torr/ } \\
\text { 理論段) }\end{array}$ & $\begin{array}{r}\text { HETP } \\
(\mathrm{cm})\end{array}$ & $\begin{array}{l}\text { ホールド } \\
\text { アップ } \\
(\mathrm{m} l / \text { / 段 })\end{array}$ \\
\hline 1,500 & 1.8 & 0.018 & 0.87 & 1.07 \\
\hline " & 4.7 & 0.022 & 0.95 & 1.35 \\
\hline " & 6.3 & 0.026 & 1.12 & 1.63 \\
\hline " & 7.0 & 0.030 & 1.04 & 1.57 \\
\hline " & 9.4 & 0.034 & 1.13 & 1.73 \\
\hline 500 & 2.8 & 0.021 & 1.09 & 1.48 \\
\hline " & 4.8 & 0.019 & 0.93 & 1.33 \\
\hline " & 5.2 & 0.021 & 0.94 & 1.36 \\
\hline " & 6.7 & 0.027 & 1.02 & 1.50 \\
\hline$"$ & 8.5 & 0.032 & 1.13 & 1.70 \\
\hline 250 & 1.0 & 0.012 & 1.06 & - \\
\hline$" \prime$ & 3.7 & 0.017 & 1.16 & - \\
\hline " & 5.6 & 0.020 & 1.23 & - \\
\hline
\end{tabular}




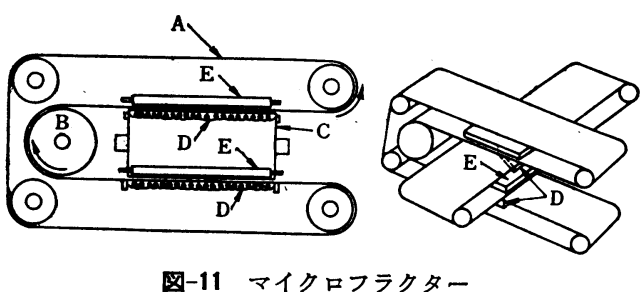

図-11 マイクロフラクター

の装置で, 長いシャフトを高速で回転させることは多分 に困難な問題があり, 今のところ, 実験的規模のものし か実用化されていない。

そのほか, 変わったところでマイクロフラクター ${ }^{8)}$ と 称する 図-11 に示したような精留器も考えられてい る。すなわちべルト Aに原液を塗布してDにより加熱し て蒸発させ,これを, 上部のベルト $\mathrm{E} に$ 凝縮させる。こ れをさらに上部に動かしてふたたび蒸発させる。還流 は，未蒸発の液がベルトの動きにつれてふたたび元にも どる仕組みになっている。この方式は精留の原理を目の 前で実現しているようなもので，とくに粘度の高い物質 の精留に適していると思われる。しかし大型の装置に応 用することには非常に困難な機械的問題が起こるである 万。

\section{$3 \cdot 4$ 真空精留の応用}

真空精留は古くから，各方面で利用されているので， もはやあまり問題がないかのように考えられているよう で, 精留塔の形式，性能に関する報告は数多くあって も，応用される物質，すなわち何を精留したとき，どの ような結果になったといらような報告はほとんどみられ ない。

しかし，石油留分のうち，重質分は真空下で精留され ているし，油脂関倸では，高級アコルール99, トール 油 $^{10)}$ などが真空精留の対象になっている。このほか，多 くの石油, 油脂類の真空精留が行なわれているはずであ り，また最近のように品質の要求が高くなればなるほ ど, 真空精留の必要性を増してくるものと思われる。

\section{4 分子蒸留装置}

戦後, 荒廃したわが国の産業復興に大きな役割を果た した肝油の輸出に対して, 分子蒸留によるビタミンAの 浱縮は非常に有効な手段として活用された。昭和 30 年 ころは全国で 30 基もの分子蒸留装置が稼動していた が, 最近では, すっかり有機合成化学の分野に株を奪わ れた感がある。すなわち，DOP を初めとする可塑剤の 連続蒸留や，TDI, MAD など略号だけでは名前の判断 さえつかないような新しい合成物の分離, 精製に分子蒸 留，または準分子蒸留的な操作が行なわれている。

\section{$4 \cdot 1$ 流下膜分子蒸留器}

ビタミンA の濃縮に活躍した分子蒸留器は 図-12 の ようなもので, 蒸発面積 $20 \mathrm{~m}^{2}$ 程度のものが作られて

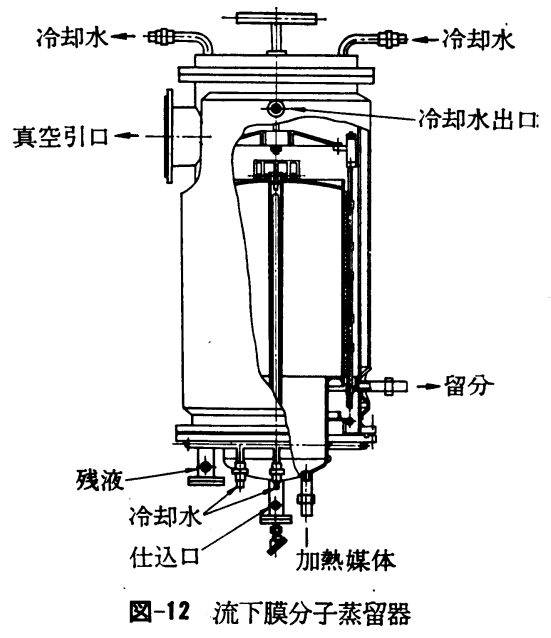

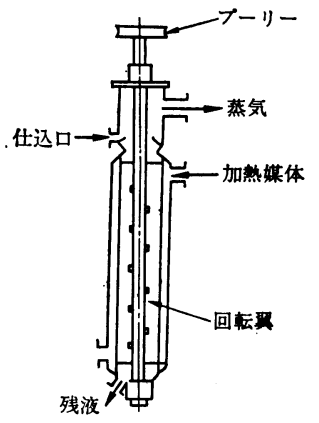

図-13 流下膜蒸留器 （ルーア式蒸留器）
(る(1)。このような大型の流 下膜蒸留器では, 液が加熱面 を流下する時間を極力短くす るために，加熱面を低くし， 代わりに径を大きく取ってい る。

また，排気口，すなわち真 空引き口の抵抗をできるだけ 少なくするために, 凝縮面を 多管式にして，その間から排 気するよらな設計も行なわれ ている。

加熱面の流下時間があまり 問題にならない場合は，筒長を大きく，径を小さくした 形式，たとえば，図-13 に示したようなものが用いられ る。これらは, 長らく外国のメーカーの特許として, 輸 入にたよっていたのであるが，最近では，これに対抗す る特許が得られたので，充分国産できるようになった。

流下膜蒸留器のポイントは, 、かに加熱面上を液が均 一に，かつすみやかに流れるかにある。このために自然 流下のみでなく機械的操作の導入によって, 目的を果た そうとしている。

ブラシ，へら，板などを加熱面上，または加熱面すれ すれのところを回転させ，液を均一化するようになって おり, それぞれワイプト蒸留器, タバフィルム蒸留器, などと称されている。流下膜蒸留器の種々の型式の解 説 ${ }^{12)}$, 性能の比較 ${ }^{13)}$ 亿関しても数多く発表されている が,ここではこの程度に止めておく。

\section{2 速心式分子蒸留器}

流下膜蒸留器では, ブラシなどで液の流下を均一にす るよう考えているが，流下そのものは，あくまで重力の みによるので，たとえば膜厚などをある程度以下にする ことはできない。 
回転する円盤の中心に液を落とせば，瞬時に遠心力で 広がり, きわめて薄い液膜の生成が可能であり, かつ, 加熱面に停滞する時間も短くてすむことは明らかで，こ れらの点が遠心式分子蒸留器の特徵よなっている。

この形式は，非常に性能がすぐれているにもかかわら ず，長い間，外国特許に抑えられて国産化されなかった が，ようやく最近，基本特許が切れて国産化が可能とな った。

同じ物質を流下膜式分子蒸留器と, 遠心式蒸留器とで 比較してみると遠心式が非常にすぐれていることがわか $ろ^{14)}$ 。

ただむずかしいのは，高速で回転する軸をシールする ことであるが，これも最近の真空技術の発達によって容 易になったので, 今後ますます普及寸るものと思われ る。

\section{$4 \cdot 3$ 実験室用分子蒸留器}

分子蒸留は有機化学の研究の一つの手段として古くか

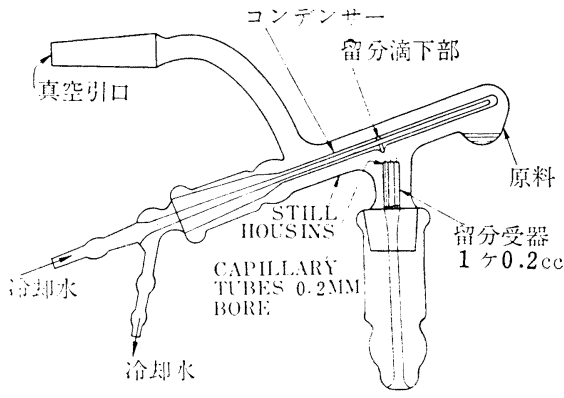

図-14 ミク口分子蒸留器

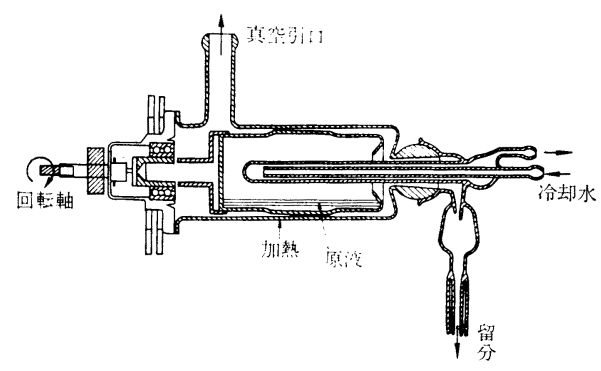

図-15 实験用回転分子等留器

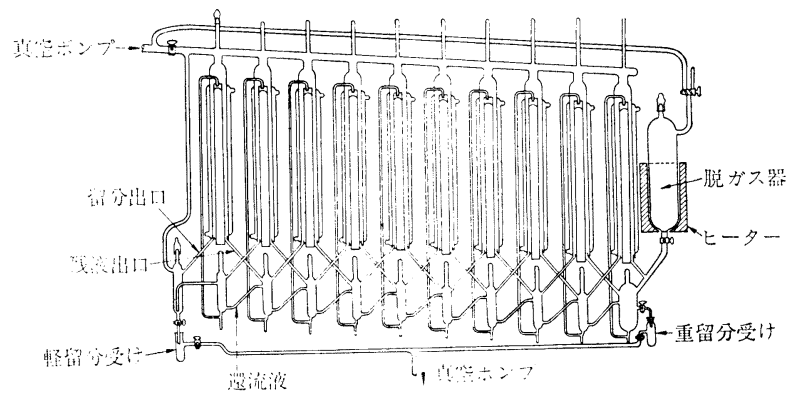

図-16 多段分子蒸留器
ら広く用いられるので，実験室規模での研究は非常に多 くの考案が提案されている。それらのらち，おもなもの を二，三図示する。

図-14 に示した装置は非常に少量の物質の分子蒸留に 用いられるもので, $1 \mathrm{~m} l$ 程度の 試料を $0.2 \mathrm{ml}$ 程度の 6 留分に分けることができる。

図-15 は同じく実験用の分子蒸留器 ${ }^{16)}$ であるが，原液 を回転させることによって薄膜を形成させる。この形式 は一部工業的にも使われている。

図-16 は, 分子蒸留器を多数連結した一種の精留器 ${ }^{17)}$ であって，この装置によって石油留分のエイコサン（炭 素数 20 の炭化水素）を分留した結果を 図-17に示す。

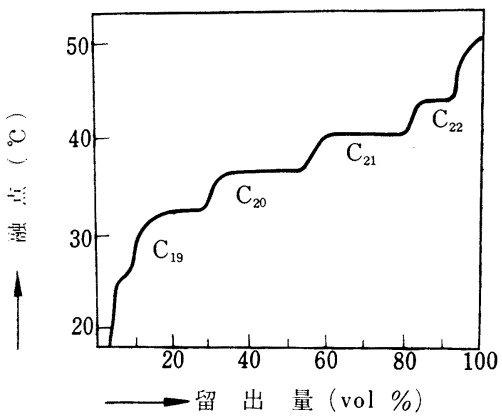

図-17 多段分子蒸留器によるエイコサン ワックス分離

表-4 分子蒸留の応用

\begin{tabular}{|c|c|}
\hline 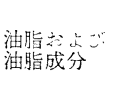 & 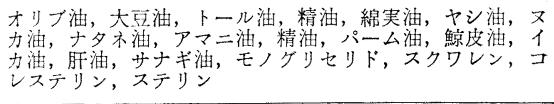 \\
\hline ビタミン類 & $\begin{array}{l}\text { ピタミンう } \mathrm{A}, \mathrm{A}_{2}, \mathrm{D}, \mathrm{E} \text {, ホルモン, キトール, カロチ } \\
\text { ン, その他 }\end{array}$ \\
\hline 脂肪跮類 & $\begin{array}{l}\text { オレイン酸, ステアリン酸, オレイルオレエーリ, セチル } \\
\text { オレエート, メチルエステ脂肪酸アミド }\end{array}$ \\
\hline ㅁ & $\begin{array}{l}\text { トウモロコンワックス，エイコサンワックス，ミッロウ， } \\
\text { 乳ロウ }\end{array}$ \\
\hline エステル & フタル酸, セバンン酸などのエステル \\
\hline 炭化水素 & ハララフィン, 石油留分, アスファルト \\
\hline 有機合成品 & $\begin{array}{l}\text { ポリエチレンゲリコール, ポリケリコール, エポキン樹脂 } \\
\text { シリコーン, ピニル重合体，ポリエチレンオキンド，コノ } \\
\text { ン }\end{array}$ \\
\hline
\end{tabular}

\section{$4 \cdot 4$ 分子蒸留の応用}

分子蒸留はいわゆる高沸点物の蒸留, 精製には 必ず使用されているといっても過言ではなく，石 油類, 油脂類に広く応用されている。その中でも

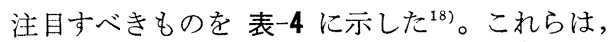
すべて工業化されているというわけではないが， 少なくとも研究段階では分子蒸留を用いたという 報告があったものばかりである。

\section{5 おわりに}

石油, 油脂関係に使われる, 真空精留と分子蒸 
留について,きわめて大体のところを紹介した。

この分野における研究，実用化はこれからますます発 展するものと思われるが，何分いまだ装置としても体系 的な研究が行なわれていない一方，それぞれの用途に対 する研究も断片的なものに止まっているので,この解説 もはなはだまとまりのないものとなってしまった。

今後の発展によって, より詳細な解説が可能となる日 を待ちたいと思う。

\section{文献}

1) K.C.D. Hickman, Chem. Rev., 54, 51 (1944)

2）中川 “真空蒸留” 真空技術講座,p. 191 (1964) 日刊工業 新聞社

3) E.S. Perry, 1956 Vacuum Symposium Trans. Am. Vac. Soc., 151 (1956)

4) C.B. Willingham et al., Ind. Eng. Chem., 39, 706 (1947)
5) R.G. Nester, 1956 Vacuum Symposium Trans. Am. Vac. Soc., 147 (1956)

6) B.J. Mais et al., J. Res. Nath. Bur. Stands., 22, 519 (1939)

7) D.F. Othemer, R.D. Beattie, Ind. Eng. Chem., 53, 799 (1961)

8) K.C.D. Hickman, 1961 Vacuum Symposium Trans. Am. Vac. Soc., 383 (1960)

9) 中川, 高橋, 真空化学 5, 103 (1957)

10) 平田, 山野井, 真空化学, 4, 151 (1956)

11）中川, “分子蒸留”新化学工学講座 (1957) 日刊工業新聞社

12) P.R. Watt "Molecular Stills" (1963) Chapman and Hall Co.

13) R. Schneider, Chem. Ing. Technik, 27, 257 (1955)

14) G. Burrows "Molecular Distillation" (1960) Oxford Clarendon Press.

15) C.W. Gould et al., Anal. Chem., 20, 361 (1948)

16) H.E. Zaugg et al., Anal. Chem., 26, 1999 (1954)

17) B.J. Mair et al., Anal. Chem., 27, 190 (1955)

18）分子蒸留の応用に関しては文献 2),12),14）に詳しい。

\section{書 評}

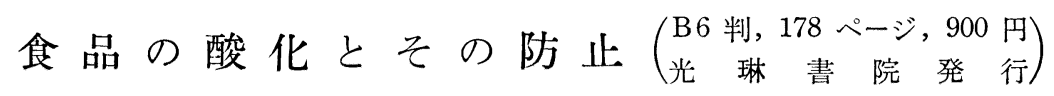

八木一文・秋 谷 年 見著

食品関係の多くの図書を出版している光琳書院から, 光琳全書の中の一つとして「食品の酸化とその防止」 が発行された。著者は油化学協会の会員であり，おなじみの深い人達である。

水分の多い食品の保存には微生物, 酵素など種々考慮すべき因子が多いが，水分の少ない食品の場合でも油 脂の酸化を始めとしてそれぞれ多くの問題点をかかえている。かく申す私自身, 食品関係の研究室に所属して いるので，種々の食品を手がけたことがあり，また食品に関する相談を受ける機会も多いのであるが，食品の 保存の問題の解決は結局最後には油脂部門にゆだねられるケースが多いことを経験している。

本書では食品の酸化とその防止の諸事項を 第 1 章 食品の成分の酸化, 第 2 章 酸化の測定法, 第 3 章 抗酸化機構と抗酸化剂, 第 4 章 食品成分内の酸化と還元, 第 5 章 各種食品の酸化とその防止に分けて解説 している。脂質の酸化のほかにアミノ酸やビタミンの酸化についても扱っており, 対象とする食品は揚げ油, マーガリン, ショートニング, マョネーズ, 畜肉, 魚肉, 牛乳, それらの加工品, 果実, そ菜, 即席めん, 1 ンスタントみそ汁，粉末ジュースなどにわたっている。

自動酸化のメカニズムや抗酸化剤の理論なども平易に解説されており，そのほか関連性のある文献が広く紹 介されている。本文全部で B6 版 200 ページ足らずで, 比較的小冊子であるが, 食品酸化の実態を知り, そ の防止の実状を認識するには充分な内容である。

保存を要する食品の範囲はきわめて広く, その現象も複雑である。食品の保存上の問題点を整理し, 解決へ の糸口を見付ける上に本書はよい参考となろう。 （太田 静行） 